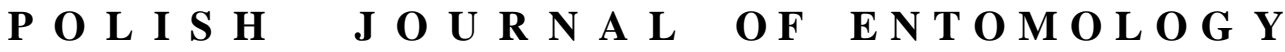

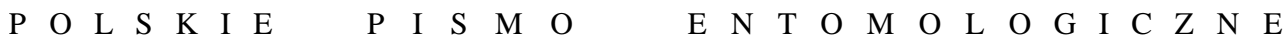

VOL. 84: $305-310$

Lublin

30 December 2015

DOI: $10.1515 /$ pjen-2015-0026

\section{An annotated checklist of burrower bugs (Hemiptera: Heteroptera: Cydnidae) from Bali (Indonesia) with new records*}

\author{
JERZY A. LIS, DARIUSZ J. ZIAJA \\ Opole University, Department of Biosystematics, Centre for Biodiversity Studies, Oleska \\ 22, 45-052 Opole, Poland, e-mails: cydnus@uni.opole.pl, d.ziaja@uni.opole.pl
}

\begin{abstract}
An annotated checklist of the Balinese Cydnidae is provided. Three species (Chilocoris adelphus, Macroscytus dominiqueae, M. javanus) are recorded for the first time from Bali, including the first Indonesian record for M. dominiqueae. Fromundus pygmaeus is recorded for the second time from the island. Our study increases the number of Cydnidae recorded from Bali to seven, and that known from Indonesia to 58 .
\end{abstract}

KEY WORDS: Hemiptera, Heteroptera, Cydnidae, Indonesia, Bali, checklist, new records.

\section{INTRODUCTION}

Although almost 200 species of Cydnidae have been recorded in the Oriental Region, only 57 are known to occur in Indonesia (LIS 1994, 1995, 1999, 2000, HUFNAGEL \& RÉDEI 2005). Most of the Indonesian burrower bug species were collected in Java, Sumatra, Borneo (Kalimantan) and Sulawesi, and only four have hitherto been reported from Bali, i.e., Cydnus horvathii (SIGNORET, 1881), Adrisa nitidicollis (STÅL, 1854), Aethus philippinensis DALLAS, 1851 and Fromundus pygmaeus (DALLAS, 1851). Because our knowledge of the Indonesian Cydnidae is still far from satisfactory, any new data are worth publishing.

\footnotetext{
* The paper is dedicated to Prof. Wacław WOJCIECHOWSKI in recognition of his great contribution to the taxonomy and faunistics of Hemiptera.
} 
We had the opportunity to study some Cydnidae specimens collected in the Bedugul Region of Bali (Tabanan Regency) in the vicinity of Lake Tamblingan. The smallest of Bali's north-western lakes, it is situated in the plateau area of Bedugul in the Sukasada District and is encircled by hills covered with rain forests (GöLTENBOTH et al. 2006). However, the ecosystem of Lake Tamblingan is threatened owing to land conversion (Delinom et al. 1997, ANSHARI et al. 2005, ADNYANA et al. 2006), so every report on the insect fauna of this region is worthy of being published.

We have identified four species: three of these are new records for the island, and one has been recorded for the first time in Indonesia. Our data increase the total number of known Balinese Cydnidae to seven and that known from Indonesia to 58.

\section{MATERIALS AND METHODS}

The study was based on Balinese specimens borrowed from the Royal Belgian Institute of Natural Sciences, Brussels (Institut royal des Sciences naturelles de Belgique, Bruxelles). All the specimens were collected in the Bedugul Region of Bali (Tabanan Regency) in 2004 and 2005 in the vicinity of Lake Tamblingan, at an altitude of 1200-1300 $\mathrm{m}$ asl.

The classification of the family follows PLUOT-SIGWALT \& LIS (2008).

\section{RESULTS AND DISCUSSION}

Four species were identified: three are new for Bali, and one is new to Indonesia as a whole. This makes a total of seven species known from Bali and 58 from Indonesia. An updated checklist of Balinese species with new records is presented below.

$$
\text { Cydninae: tribe Cydnini }
$$

\section{Chilocoris adelphus HORVÁTH, 1919}

Chilocoris adelphus HoRVÁTH, 1919: 260.

Type data: Lectotype male (designated by Lis 1991b: 300): Indonesia, South Celebes, Bua-Kraeng (Hungarian Natural History Museum, Budapest, Hungary).

Material examined: 4우, 2-17.II.2004, I.G. 31.175, 1200 m, St. JAKL lgt.; 11 $\widehat{\jmath}$, 8 우, 18-28-II-2004, 1200 m, I.G. 31.175, lgt. St. JAKL; 1 , III-2004/1200 m, I.G. 31175, lgt. St. JAKL; 2 우, 1300 m, V-2005, I.G. 31.175, lgt St. JAKL.

General distribution: Indonesia (Bali - first record, Java, Sulawesi, West Timor) (LIS 1991b, 1994, 1999). 
Distribution in Bali: Lake Tamblingan in Tabanan Regency (present paper).

\section{Cydnus horvathii (SIGNORET, 1881)}

Cydnopeltus horvathii SIGNORET, 1881a: 28.

Cydnus horvathii: LIS 1997: 405.

Type data: Lectotype male (designated by LIS 1994: 96): Indonesia, Java (Hungarian Natural History Museum, Budapest, Hungary).

General distribution: Indonesia (Bali, Java), South India (LIS 1994, 1997, 1999)

Distribution in Bali: Kintamani in Bangli Regency (LIS 1994).

$$
\text { Cydninae: Geotomini s. lato }
$$

\section{Adrisa nitidicollis (STÅL, 1854)}

Acatalectus nitidicollis STÅL, 1854: 232.

Adrisa nitidicollis: SIGNORET, 1881b: 208.

Type data: Lectotype male (designated by LIS 1992: 22): Indonesia, Java (Swedish Museum of Natural History, Stockholm, Sweden).

General distribution: Indonesia (Bali, Java, Lombok), Philippines (LIS 1992, 1994, 1996, 1999).

Distribution in Bali: Kintamani in Bangli Regency, Tamblang in Buleleng Regency (LIS 1994).

\section{Aethus philippinensis DALLAS, 1851}

Aethus philippinensis DALLAS, 1851: 118.

Type data: Lectotype male of Aethus philippinensis DALLAS, 1851 (designated by LIS 1993: 109): Philippines (Natural History Museum, London, U.K.).

General distribution: Australia, Bismarck Archipelago, India (South), Indonesia (Bali, Borneo, Flores, Halmahera, Java, New Guinea, Sulawesi, Sumatra, Timor), Malaysia, Nicobar Islands, Papua New Guinea, Philippines, Singapore, Solomon Islands (LIS 1993, 1994, 1996, 1999, 2006).

Distribution in Bali: general, without exact locality (LIS 1993); the occurrence of this species in Bali needs confirmation.

\section{Fromundus pygmaeus (DALLAS, 1851)}

Aethus pygmaeus DALLAS, 1851: 120.

Fromundus pygmaeus: LIS, 1994: 181.

Type data: Lectotype female of Aethus pygmaeus DALLAS, 1851 (designated by LIS 1994: 182): India (Natural History Museum, London, U.K.). 
Material examined: 1 \%, 1 , 1200 m, VII.2004, I.G. 31.175, lgt St. JAKL.

General distribution: Widely distributed in the Oriental and Australian Regions; also known from the southern Asiatic parts of the Palearctic Region; the westernmost records come from the Afrotropical Seychelles (LIS 1994, 1996, 1999, 2006, 2013, HUfNAGEL \& RÉDEI 2005).

Distribution in Bali: Very common in Indonesia, but in Bali reported only once from the beach at Kuta in Badung Regency, so far (Lis 1994); the locality reported here (Lake Tamblingan in Tabanan Regency) is the second in the island. These two localities (one in the north, the other in the south of the island) may suggest that $F$. pygmaeus is common in Bali as well.

\section{Macroscytus dominiqueae J.A. LIS, 1991}

Macroscytus dominiqueae J.A. LIS, 1991a: 209.

Type data: Holotype male: Vietnam, Cho-Ganh (Muséum National d'Histoire Naturelle, Paris, France).

Material examined: $1 \hat{\delta}$, 3 우, III-2004/1200 m, I.G. 31.175, lgt. St. JAKL; $1 \hat{\delta}, 1300$ m,

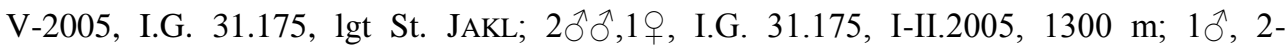
17.II.2004, I.G. 31.175, 1200 m. St. JAKL lgt.

General distribution: Cambodia, China (Hong Kong, Yunnan), India, Indonesia (Bali) - first record, Laos, Malaya, Vietnam, Thailand (LIS 1991a, 1994, 2000, 2006, ZHU et al. 2010).

Distribution in Bali: Lake Tamblingan in Tabanan Regency (present paper).

\section{Macroscytus javanus MAYR, 1866}

Macroscytus javanus MAYR, 1866: 361.

Type data: Lectotype male (designated by LIS 1994: 240): Indonesia, Java (Naturhistorisches Museum Wien, Vienna, Austria).

Material examined: 1ㅇ, 2-17.II.2004, I.G. 31.175, 1200 m, St. JAKL lgt.

General distribution: Indonesia (Bali - first record, Sumatra, Java, Engano, Lombok, Solor, Sumbawa, Sulawesi), Malaysia (Malaya), Singapore, Thailand (LIS 1994, 1999, 2000).

Distribution in Bali: Lake Tamblingan in Tabanan Regency (present paper).

\section{ACKNOWLEDGEMENTS}

The authors express their gratitude to Jerome CONSTANT (Royal Belgian Institute of Natural Sciences, Department of Entomology) for the loan of material used in this study. 
Special thanks go to Petr KMENT (Department of Entomology, National Museum, Prague, Czech Republic) and Philippe MaGnIEN (Département Systématique \& Evolution, Muséum National d'Histoire Naturelle, Paris, France) for their comments and suggestions on the manuscript. This project was supported by Opole University Grant No. 1/KBI/15-S.

\section{REFERENCES}

Adnyana I.W.S., Nishio F., Sumantyo J.T.S., Hendrawan G. 2006. Monitoring of land use changes using aerial photograph and ikonos image in Bedugul, Bali. International Journal of Remote Sensing and Earth Sciences 3: 5157.

Anshari G. Z., MoEdjodo H., ANDriJAnto, Suharso Y. 2005. Roles of government, scientists and NPOs in the development of Indonesia Lake Vision. [in:] E.O. OdADA, D.O. OlaGo, W. OchOla, M. NTiBA, S. WANDiga, N.N. GichuKi, H.A. OYIEKE (eds.). Proceedings of the $11^{\text {th }}$ World Lakes Conference, Nairobi, Kenya. UNEP/World Lakes Committee, Nairobi, Kenya, 1-6.

Dallas W. 1851. List of specimens of Hemipterous insects in the collection of the British Museum. Part I. Taylor, London.

Delinom R.M., Duuansah M., SiRegar S. 1997. Hydrological Behavior of Lake Bratan, Lake Buyan, and Lake Tamblingan, Bali: A Water Balance Approach. [in:] B. MAChBUB, P.E. Hehanussa, N. Terangna (eds.). Proceedings of Workshop on Ecosystem Approach to Lake and Reservoir Management, Kuta, Bali, 22-25 July 1997. IHP Regional Steering Committee for Southeast Asia and the Pacific, Langkawi, Malaysia, 37-50.

Göltenboth F., Timotius K.H., Milan P.P., Margraf J. (eds.) 2006. Ecology of insular Southeast Asia. The Indonesian Archipelago. Elsevier, Amsterdam - Boston - Heidelberg - London - New York - Oxford - Paris - San Diego - San Francisco - Singapore - Sydney -Tokyo.

HorvÁth G. 1919. Analecta ad cognitionem Cydnidarum. Annales Historico-Naturales Musei Nationalis Hungarici 17: 205-273.

Hufnagel L., RÉDei D. 2005. Cydnidae (Heteroptera) from the Oriental Region and New Guinea. Folia Entomologica Hungarica 66: 9-15.

Lis J.A. 1991a. Studies on Oriental Cydnidae. V. Three new species of the genus Macroscytus FiEBER (Heteroptera). Annals of the Upper Silesian Museum, Entomology 2: 209-215.

LIS J.A. 1991b. Studies on Oriental Cydnidae. VI. A contribution to the fauna of Sulawesi (Celebes) (Heteroptera: Pentatomoidea). Genus 2(4): 299-311.

Lis J.A. 1992. Studies on Oriental Cydnidae. IX. On the genus Adrisa AmYOT and SERVILLe, 1843 (Heteroptera: Pentatomoidea). Genus 3(1): 13-27.

Lis J.A. 1993. Studies on Oriental Cydnidae. VIII. On Aethus indicus (Westwood), A. philippinensis DALlas and A. pseudindicus n. sp. (Heteroptera: Pentatomoidea). Genus 4(2): 103-111.

Lis J.A. 1994. A revision of Oriental burrower bugs (Heteroptera: Cydnidae). Upper Silesian Museum, Bytom.

LIS J.A. 1995. The genus Macroscytus FIEBER (Heteroptera: Cydnidae) in the East Palaearctic subregion. Entomologische Berichten 55(10): 163-165. 
Lis J.A. 1996. A review of burrower bugs of the Australian Region, with a discussion on the distribution of the genera (Hemiptera: Heteroptera: Cydnidae). Genus 7(2): 177-238.

Lis J.A. 1997. Taxonomy and phylogeny of the genus Cydnus F., 1803 (Hemiptera: Heteroptera: Cydnidae). Annales de la Société Entomologique de France (N.S.) 32(4): 403-409.

LIS J.A. 1999. Burrower bugs of the Old World - a catalogue (Hemiptera: Heteroptera: Cydnidae). Genus 10(2): 165-249.

LIS J.A. 2000. A revision of the burrower-bug genus Macroscytus FIEBER, 1860 (Hemiptera: Heteroptera: Cydnidae). Genus 11(3): 359-509.

Lis J.A. 2006. Cydnidae Billberg, 1820 - burrowing bugs (burrower bugs) [in:] B. AukemA, C. Rieger (eds.). Catalogue of the Heteroptera of the Palaearctic Region. Volume 5. Pentatomomorpha II. The Netherlands Entomological Society, Wageningen, 119-147.

Lis J.A. 2013. Family Cydnidae Billberg, 1820 [in:] J. Gerlach (ed.). Odonata, Hemiptera, Hymenoptera and other insects of the Seychelles. Siri Scientific Press, Manchester, 132-135.

MAYR G.L. 1866. Diagnosen neuer Hemipteren III. Verhandlungen der Zoologisch-Botanischen Gesellschaft in Wien 16: 361-366.

Pluot-Sigwalt D., Lis J.A. 2008. Morphology of the spermatheca in the Cydnidae (Hemiptera: Heteroptera): Bearing of its diversity on classification and phylogeny. European Journal of Entomology 105(2): 279-312.

SignORET V. 1881a. Descriptions de deux genres nouveaux d'Hémiptères de la division des Cydnides. Bulletin de la Société Entomologique de France 1881: 28-29.

Signoret V. 1881b. Révision du Groupe des Cydnides de la Famille des Pentatomides. 2e partie (1). Annales de la Société Entomologique de France (6 ser.) 1: 193-218.

STÅL C. 1854. Nya Hemiptera. Öfversigt af Kongliga Vetenskaps-Akademiens Förhandlingar 11: 231-255.

Zhu G.P., Liu G.Q., Lis J.A. 2010. A study on the genus Macroscytus Fieber, 1860 from China (Hemiptera: Heteroptera: Cydnidae). Zootaxa 2400: 1-15.

Received: 6 July 2015

Accepted: 24 July 2015 